REPORTS OF MORPHOLOGY
$\begin{gathered}\text { Official Journal of the Scientific Society of Anatomists, } \\ \text { Histologists, Embryologists and Topographic Anatomists } \\ \text { of Ukraine } \\ \text { journal homepage: https://morphology-journal.com }\end{gathered}$

\title{
Evaluation of embryotoxicity and fetotoxicity of Clindamycin phosphate under normal and elevated levels of serum Hydrogen
}

\section{sulfide in rats}

Taran I.V., Grebeniuk D.I., Voloshchuk N.I., Lozinska M.S., Nazarchuk O.A., Bodnarchuk O.V. National Pirogov Memorial Medical University, Vinnytsya, Ukraine

\section{ARTICLE INFO}

Received: 17 February 2021

Accepted: 7 April 2021

UDC: $577.18+546.221 .1+615.099 .092$

\section{CORRESPONDING AUTHOR}

e-mail: doctor.svo@gmail.com Grebeniuk D.I.

\begin{abstract}
Widespread use of antibiotics in clinical practice leads to the development of antibiotic resistance and encourages the search for new ways of modulation of their therapeutic effect. One of the potentially successful modulators may be Hydrogen sulfide, but the mechanisms of its action require careful studies, including toxicological. The aim of the study was to study the effect of Hydrogen sulfide levels on the embryotoxicity and fetotoxicity of oral and intravaginal Clindamycin phosphate administration. The experimental study was performed on 60 pregnant female rats, which were divided into 6 experimental groups: group 1 - control group; group 2 - high level of serum Hydrogen sulfide; group 3 - Clindamycin phosphate intravaginally; group 4 - Clindamycin phosphate intravaginally with high level of serum Hydrogen sulfide; group 5 - Clindamycin phosphate orally; group 6 - Clindamycin phosphate orally with high level of serum Hydrogen sulfide. We studied the dynamics of weight gain in pregnant rats, the number of corpora lutea, the number of implantation sites in the uterus, the number of live and dead fetuses, preimplantation and postimplantation mortality, as well as the dynamics of body weight gain and mental development of offspring. Artificially increasing the serum level of Hydrogen sulfide in pregnant rats led to an increase in maternal weight gain, an increase in the weight and cranio-caudal size of embryos, as well as a decrease in the number of resorbed fetuses and postimplantation mortality. The insignificant toxic effect of high doses of oral Clindamycin phosphate was leveled in the group with elevated indices of serum Hydrogen sulfide. Rats born to females with elevated levels of serum Hydrogen sulfide showed faster rates of weight gain and normal mental development according to the "open field" test.

Keywords: Clindamycin phosphate, Hydrogen sulfide, embryotoxicity, fetotoxicity.
\end{abstract}

\section{Introduction}

Treatment of patients with drugs from the group of antibiotics requires a balanced and professional approach, which is part of the concept of rational use of drugs. In turn, the rational use of antibiotics is an important part of the Ministry of Health's postulates, which should improve the prognosis of patients' recovery and reduce the length of hospital stay. However, despite the titanic efforts of the WHO and family doctors, the problem of controlling the circulation of antibiotics and their use by patients themselves remains. The main ones are uncontrolled intake, unauthorized discontinuation of antibiotics, self-increase or decrease in dose of drugs and, ultimately, the use of these potentially dangerous drugs without urgent need [8, 10, 19, 28].

All the principles of rational antibiotic therapy are divided into two major groups:

1. a group of principles and rules from the doctor and the manufacturer of the antibiotic;

2. a group of rules on the part of the patient.

If the second group can be little influenced by specialists, then the first group must be thoroughly studied, improved and create new approaches to antibiotic therapy.

In view of this, in recent years in the world literature there is information about the action of a number of endogenous factors that change the body's response to inflammation and septic conditions, which often use antibiotics. Such factors include the levels of vasoactive molecules, among which the most important is Hydrogen sulfide $[9,12,13,29,31]$. 
One of the most important issues in assessing the toxic effects of antibiotics on the human body is to determine the indicators of fetotoxicity and embryotoxicity.

One of the antibacterial agents widely used in gynecological practice, including for pregnant women, is a member of the group of lincosamides - the drug clindamycin $[14,15,17,21,23,25]$. In the scientific literature there are reports of possible adverse effects of this drug on the course of labor and the condition of the fetus [1]. That is why, in our opinion, it is relevant both from a scientific and practical point of view to study the effect of Hydrogen sulfide on the reproductive toxicity of antibiotics, in particular clindamycin.

The aim of the research was to study the effect of Hydrogen sulfide levels on the indicators of embryotoxicity and fetotoxicity of Clindamycin phosphate under conditions of oral and intravaginal administration.

\section{Materials and methods}

The experimental study was performed on 60 pregnant female rats weighing $200-240$ grams $(219.7 \pm 11.1$ grams) and under 1 year of age.

All experiments were performed in accordance with the "Regulations on the use of animals in biomedical experiments" with the permission of the Bioethics Committee and in accordance with the provisions of Directive 2010/63/ EU of the European Parliament and of the Council of 22 September 2010 "On the protection of animals used for scientific purposes".

Next, the experimental animals were divided into experimental groups as follows:

1 group ( $n=10)$ - control group - animals that received a solution of phosphate buffer.

Group $2(n=10)$ - animals, which created an excess of serum Hydrogen sulfide.

Group $3(n=10)$ - animals treated with Clindamycin phosphate intravaginally.

Group $4(n=10)$ - animals injected with Clindamycin phosphate intravaginally on the background of excess serum Hydrogen sulfide.

Group $5(n=10)$ - animals administered Clindamycin phosphate orally.

Group $6(n=10)$ - animals administered Clindamycin phosphate orally on the background of excess serum Hydrogen sulfide.

All drugs were administered throughout pregnancy.

The phosphate buffer solution was administered orally through a $0.5 \mathrm{ml}$ tube once a day.

Oral Clindamycin phosphate (Union Quimico Farmaceutica, S.A., Spain) was administered on a $1 \%$ starch gel via a tube once a day. The dose of the drug was equivalent to the maximum daily dose and according to the conversion tables was $500 \mathrm{mg} / \mathrm{kg}$ [22].

Intravaginally, Clindamycin phosphate (Pfizer Inc., USA) was administered to rats as micro-suppositories once daily. The dose of the drug according to the conversion tables was $1.5 \mathrm{mg}$ [22]. Given that the suppository contains 100 $\mathrm{mg}$ of active substance and its weight is 2.5 grams, and based on the fact that the active substance is distributed evenly in the suppository, to provide an equivalent dose (1.5 $\mathrm{mg}$ of Clindamycin phosphate) we formed microsuppositories weighing $37.5 \mathrm{mg}$.

Excess Hydrogen sulfide in animals was created by intraperitoneal administration of Hydrogen sulfide donor sodium hydrosulfide (NaHS, Sigma-Aldrich, USA) at a dose of $1.5 \mathrm{mg} / \mathrm{kg}$ on $0.1 \mathrm{M}$ phosphate buffer ( $\mathrm{pH} 7.4)$, in the form of freshly made aqueous solution at the rate of $0.1 \mathrm{ml}$ per $100 \mathrm{~g}$ of rat weight, 1 time per day [27].

On day 5 of the study, the content of Hydrogen sulfide in the serum was determined. To do this, all rats were bled from the tail vein. The serum of the obtained blood was examined by spectrophotometric method in the reaction between sulfide anion and para-phenylenediamine hydrochloride in an acidic environment in the presence of iron ions (III) [27].

Throughout the experiment, the general condition of the rats, behavior and dynamics of weight gain were observed. On days 7,14 and 20, the weight gain of pregnant rats relative to baseline values was assessed.

On day 20, half of the 7 rats from each group were removed from the experiment by translocating the cervical vertebrae under ketamine anesthesia at the rate of $0.22 \mathrm{ml}$ of ketamine per 100 grams of body weight of the experimental animal. A laparotomy was performed, after which the pregnant uterus was examined (Fig. 1).

The number of corpora lutea in the ovaries, the number of implantation sites in the uterus, the number of live and dead fetuses were recorded. Based on the obtained data, the term of fetal death was determined - before or after implantation.

Preimplantation (PrelL) and postimplantation (PostIL) mortality were determined by the formulas:

1. PrelL $=(C-(A+B)) / C * 100 \%$;

2. PostlL $=B /(A+B)^{*} 100 \%$,

where $A$ is the number of live fetuses, $B$ is the number of

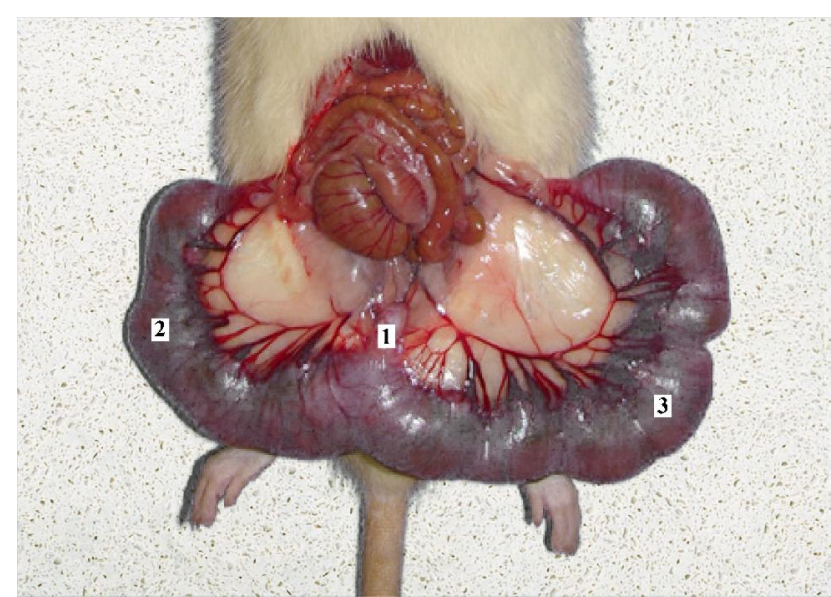

Fig. 1. Pregnant uterus removed into a laparotomy wound. 1 cervix; 2, 3 - right and left uterine horns with embryos. 
dead (resorbed) fetuses, $\mathrm{C}$ is the number of corpora lutea of pregnancy.

Fetuses were examined for visible mutations, sex, weight, and cranio-caudal size were determined. After that, part of the fetuses was fixed in Buen's solution to study the condition of the internal organs on serial sections. The rest of the fetuses was immersed in a solution of $96 \%$ ethanol and stained by the Dawson method to assess ossification points.

The rest of the rats were observed before birth. After birth, the number of newborn males and females was counted, and the weight of rats was measured at 5, 15, 30, and 50 days. In addition, for 30 days, 7 males and 7 females were randomly selected from rats born in each group, which were assessed for anxiety and mental development of offspring on the "open field" model.

The obtained data were processed using the statistical software package SPSS 20.0 for Windows.

\section{Results}

In all groups and at all times of the study, no behavioral changes were observed in experimental animals. All rats maintained normal motor activity. Consumption of feed and water met the standards for this species.

The levels of serum Hydrogen sulfide in the groups of experimental animals are shown in Fig. 2.

In all groups where the excess of serum Hydrogen sulfide was artificially simulated, there was a significant increase $(p<0.01)$ of this indicator by $11-12 \%$ compared to the groups that did not receive Hydrogen sulfide donors.

When assessing the dynamics of weight gain in pregnant female rats, the following data were obtained. During the first week, there was almost the same weight gain in all experimental animals.

In the second group (excess Hydrogen sulfide), the animals gained weight significantly faster than in the control group. Thus, the weight gain was higher compared to the control group by $15.35 \%$ in the second week and by $15.22 \%$ in 15-20 days of the study.

The studied indicator in the group with intravaginal administration of Clindamycin phosphate did not differ significantly from the control group at all terms of the study. At the same time, rats with intravaginal administration of Clindamycin phosphate on the background of excess

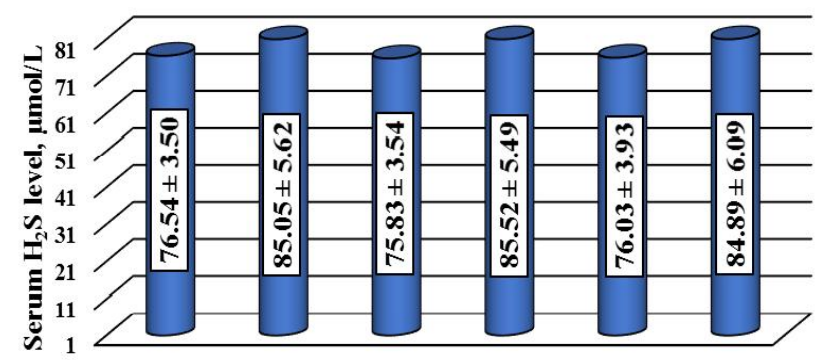

Group 1 Group 2 Group 3 Group 4 Group 5 Group 6

Fig. 2. Serum Hydrogen sulfide levels in groups of experimental animals.
Hydrogen sulfide gained weight in almost the same way as rats from group 2 - weight gain exceeded the control group by $14.47 \%$ in the second week and $14.33 \%$ in $15-20$ days of research, respectively.

Although in the group with oral Clindamycin phosphate the numerical values of weight gain were slightly lower than the value of this indicator in the control group, but statistically significant differences between the groups were not confirmed at any time in the study. Similarly, no statistically significant difference was found between the indicators of group 6 and the control group, although the numerical values in group 6 were slightly higher. In this case, both on the 14th and on the 20th day of the study, weight gain in rats of group 6 significantly exceeded the same indicator of group 5 .

Detailed values of weight gain of experimental animals in all study groups are shown in Table 1.

The indicators we evaluated on the 20th day of the study are shown in Table 2.

At visual inspection of fetuses visible mutations were not defined by us, ossification points in groups 2-6 did not differ from group 1 (control group).

Fetuses had the largest mass and cranio-caudal size in groups 2 and 4, the smallest - in group 5, and the differences were statistically significant. In groups 1, 3 and 6 these indicators were almost identical.

The number of corpora lutea, as well as the number of live fetuses in the groups did not differ significantly. At the same time, the number of resorbed fetuses was significantly lower in groups 2 and 4 . The largest number of resorbed fetuses was in group 5, although not statistically significantly higher than in the control group.

Regarding the indicators of intrauterine mortality, preimplantation mortality did not differ significantly in all groups. Postimplantation mortality was highest in the group with oral Clindamycin phosphate, although no significant differences from the control group were confirmed. The lowest rates of postimplantation mortality occurred in the groups with additional administration of sodium hydrosulfide, and the indicators of groups 2 and 4 were statistically significantly higher than the groups with the usual background level of Hydrogen sulfide.

The next stage of our study was to establish the effect of the studied substances on the physical and mental development of the offspring.

No fatalities were reported during the 50-day study. All rats were active, behavioral reactions, timing of hair, weight gain met age standards.

The dynamics of weight gain in rats are shown in Table 3.

In male rats born from animals of group 2, on the 15th and 30th day of life, body weight significantly exceeded those of groups 1 and 5, and on the 50th day - only a similar indicator of group 5. In female rats born from animals of group 2, body weight significantly exceeded that in groups 1 and 5 on days 15,30 and 50 of the study. 
Table 1. Estimation of weight gain of pregnant rats $(\mathrm{M} \pm \mathrm{m})$.

\begin{tabular}{|l|c|c|c|c|}
\hline \multirow{2}{*}{\multicolumn{1}{c|}{ Groups of animals }} & \multirow{2}{*}{$\begin{array}{c}\text { Initial weight, } \\
\text { grams }\end{array}$} & \multicolumn{3}{c|}{ Weight gain for the specified period, grams } \\
\cline { 3 - 5 } & & $1-7$ days & $8-14$ days & $15-20$ days \\
\hline 1. Control (Phosphate buffer) & $219.0 \pm 14.9$ & $15.20 \pm 3.77$ & $22.80 \pm 3.43^{\star 2,4}$ & $33.50 \pm 5.32^{\star 2,4}$ \\
\hline 2. NaHS & $219.6 \pm 12.7$ & $16.20 \pm 1.62$ & $26.30 \pm 3.27^{\star 1,3,5}$ & $38.60 \pm 3.27^{\star 1,3,5}$ \\
\hline 3. Clindamycin phosphate intravaginally & $221.6 \pm 10.5$ & $15.00 \pm 2.16$ & $22.50 \pm 2.37^{\star 2,4}$ & $33.10 \pm 4.23^{\star 2,4}$ \\
\hline 4. Clindamycin phosphate intravaginally + NaHS & $221.9 \pm 10.3$ & $15.10 \pm 1.79$ & $26.10 \pm 2.51^{\star 1,3,5}$ & $38.30 \pm 3.40^{\star 1,3,5}$ \\
\hline 5. Clindamycin phosphate orally & $217.3 \pm 5.4$ & $14.70 \pm 1.95$ & $19.40 \pm 4.22^{\star 2,4,6}$ & $31.60 \pm 2.99^{\star 2,4,6}$ \\
\hline 6. Clindamycin phosphate orally + NaHS & $218.8 \pm 12.5$ & $15.20 \pm 3.55$ & $23.80 \pm 3.16^{\star 5}$ & $36.50 \pm 4.22^{\star 5}$ \\
\hline
\end{tabular}

Notes (hereinafter): * - statistically significant difference compared with the control group. The numbers indicate the group number, in comparison with which the differences are significant.

Table 2. Evaluation of the effect of the studied compounds on the embryonic development of rats $(\mathrm{M} \pm \mathrm{m})$.

\begin{tabular}{|c|c|c|c|c|c|c|c|}
\hline \multirow[b]{2}{*}{$\begin{array}{l}\text { Groups of } \\
\text { animals }\end{array}$} & \multirow[b]{2}{*}{$\begin{array}{l}\text { Fetus weight, } \\
\text { grams }\end{array}$} & \multirow[b]{2}{*}{ Fetus size, $\mathrm{cm}$} & \multicolumn{5}{|c|}{ For 1 female } \\
\hline & & & $\begin{array}{c}\text { Number of } \\
\text { corpora lutea } \\
\text { of pregnancy }\end{array}$ & $\begin{array}{l}\text { Number of } \\
\text { live fetus }\end{array}$ & $\begin{array}{l}\text { Number of } \\
\text { resorbed fetus }\end{array}$ & Prell & PostlL \\
\hline $\begin{array}{l}\text { 1. Control } \\
\text { (Phosphate } \\
\text { buffer) }\end{array}$ & $3.086 \pm 0.367^{\star 2,4}$ & $2.871 \pm 0.350^{\star 2,4}$ & $13.43 \pm 1.27$ & $10.86 \pm 1.07$ & $1.429 \pm 0.787^{\star 2}$ & $8.456 \pm 4.971$ & $11.43 \pm 6.26^{* 2}$ \\
\hline 2. $\mathrm{NaHS}$ & $3.457 \pm 0.207^{\star 1,3,5}$ & $3.214 \pm 0.168^{\star 1,3,5}$ & $13.29 \pm 0.95$ & $11.29 \pm 1.11$ & $0.571 \pm 0.535^{\star 1,3,5}$ & $10.53 \pm 8.86$ & $4.817 \pm 4.571^{* 1,3,5}$ \\
\hline $\begin{array}{l}\text { 3. Clindamycin } \\
\text { phosphate } \\
\text { intravaginally }\end{array}$ & $3.100 \pm 0.231^{\star 2,4}$ & $2.886 \pm 0.204^{\star 2,4}$ & $13.86 \pm 1.21$ & $10.57 \pm 1.27$ & $1.571 \pm 0.535^{\star 2,4}$ & $12.48 \pm 3.82$ & $12.93 \pm 4.21^{\star 2,4}$ \\
\hline $\begin{array}{l}\text { 4. Clindamycin } \\
\text { phosphate } \\
\text { intravaginally + } \\
\text { NaHS }\end{array}$ & $3.429 \pm 0.189^{\star 1,3,5}$ & $3.186 \pm 0.135^{\star 1,3,5}$ & $12.71 \pm 1.50$ & $10.71 \pm 1.25$ & $0.714 \pm 0.488^{\star 3,5}$ & $9.810 \pm 5.487$ & $6.294 \pm 4.330 * 3,5$ \\
\hline $\begin{array}{l}\text { 5. Clindamycin } \\
\text { phosphate orally }\end{array}$ & $2.800 \pm 0.289^{\star 2,4,6}$ & $2.614 \pm 0.261^{\star 2,4,6}$ & $13.14 \pm 1.77$ & $9.857 \pm 2.193$ & $1.857 \pm 0.900^{\star 2,4,6}$ & $11.35 \pm 5.36$ & $16.22 \pm 9.00^{\star 2,4,6}$ \\
\hline $\begin{array}{l}\text { 6. Clindamycin } \\
\text { phosphate orally } \\
+\mathrm{NaHS}\end{array}$ & $3.200 \pm 0.306^{\star 5}$ & $3.014 \pm 0.313^{\star 5}$ & $13.43 \pm 1.27$ & $11.00 \pm 1.41$ & $0.857 \pm 0.690 * 5$ & $11.68 \pm 3.76$ & $7.306 \pm 5.847^{\star 5}$ \\
\hline
\end{tabular}

Notes: PrelL - preimplantation mortality. PostlL - postimplantation mortality.

Table 3. Dynamics of weight gain of rats from 5 to 50 days of life $(M \pm m)$.

\begin{tabular}{|c|c|c|c|c|c|}
\hline \multirow{2}{*}{ Groups of animals } & \multirow{2}{*}{ Sex } & \multicolumn{4}{|c|}{ Day of life } \\
\hline & & 5 & 15 & 30 & 50 \\
\hline \multirow{2}{*}{$\begin{array}{l}\text { 1. Control (Phosphate } \\
\text { buffer) }\end{array}$} & Males & $11.37 \pm 0.89$ & $22.21 \pm 1.19^{* 2}$ & $43.01 \pm 2.12^{\star 2}$ & $76.71 \pm 2.47$ \\
\hline & Females & $11.44 \pm 0.85$ & $22.37 \pm 1.25^{\star 2}$ & $43.17 \pm 2.17^{\star 2}$ & $76.59 \pm 2.59^{\star 2}$ \\
\hline \multirow{2}{*}{ 2. NaHS } & Males & $12.24 \pm 1.10$ & $23.80 \pm 1.30^{* 1,5}$ & $46.03 \pm 2.26^{* 1,5}$ & $78.81 \pm 2.81^{\star 5}$ \\
\hline & Females & $12.30 \pm 1.13$ & $24.20 \pm 1.63^{\star 1,5}$ & $46.19 \pm 2.20^{\star 1,5}$ & $79.53 \pm 2.27^{\star 1,5}$ \\
\hline \multirow{2}{*}{$\begin{array}{l}\text { 3. Clindamycin } \\
\text { phosphate } \\
\text { intravaginally }\end{array}$} & Males & $11.87 \pm 0.71$ & $22.83 \pm 1.02$ & $45.40 \pm 2.09$ & $77.03 \pm 2.09$ \\
\hline & Females & $12.01 \pm 0.74$ & $23.03 \pm 1.16$ & $45.53 \pm 1.97$ & $77.03 \pm 2.09$ \\
\hline \multirow{2}{*}{$\begin{array}{l}\text { 4. Clindamycin } \\
\text { phosphate } \\
\text { intravaginally + } \\
\text { NaHS }\end{array}$} & Males & $11.61 \pm 0.95$ & $22.44 \pm 1.11$ & $45.17 \pm 2.16$ & $77.11 \pm 1.43$ \\
\hline & Females & $11,61 \pm 0,95$ & $22,60 \pm 1,18$ & $45,30 \pm 1,90$ & $77,47 \pm 1,37$ \\
\hline \multirow{2}{*}{$\begin{array}{l}\text { 5. Clindamycin phosphate } \\
\text { orally }\end{array}$} & Males & $11,26 \pm 1,12$ & $22,30 \pm 1,24^{\star 2}$ & $43,33 \pm 2,08^{\star 2}$ & $75,23 \pm 2,26^{\star 2}$ \\
\hline & Females & $11,41 \pm 0,92$ & $22,44 \pm 1,02^{\star 2}$ & $43,49 \pm 2,21^{\star 2}$ & $75,39 \pm 2,34^{\star 2}$ \\
\hline \multirow{2}{*}{$\begin{array}{l}\text { 6. Clindamycin phosphate } \\
\text { orally }+\mathrm{NaHS}\end{array}$} & Males & $11,34 \pm 0,86$ & $22,31 \pm 1,29$ & $44,04 \pm 1,76$ & $76,16 \pm 2,24$ \\
\hline & Females & $11,56 \pm 0,71$ & $22,63 \pm 1,17$ & $44,20 \pm 1,90$ & $77,07 \pm 2,18$ \\
\hline
\end{tabular}


Table 4. Evaluation of behavioral responses in the open field test model $(M \pm m)$.

\begin{tabular}{|l|c|c|c|c|c|}
\hline \multicolumn{1}{|c|}{ Groups of animals } & Sex & Ambulations & Grooming & Rering & Defecation \\
\hline \multirow{2}{*}{ 1. Control (Phosphate buffer) } & Males & $16.14 \pm 0.69$ & $7.286 \pm 1.113$ & $3.429 \pm 1.272$ & $0.714 \pm 0.488$ \\
\cline { 2 - 6 } & Females & $15.57 \pm 0.98$ & $8.857 \pm 1.069$ & $3.571 \pm 1.397$ & $1.000 \pm 0.577$ \\
\hline \multirow{2}{*}{ 2. NaHS } & Males & $15.86 \pm 0.90$ & $7.429 \pm 1.134$ & $3.143 \pm 1.345$ & $0.857 \pm 0.690$ \\
\cline { 2 - 6 } & Females & $15.43 \pm 1.27$ & $9.143 \pm 0.690$ & $2.571 \pm 0.976$ & $0.571 \pm 0.535$ \\
\hline \multirow{2}{*}{$\begin{array}{l}\text { 3. Clindamycin } \\
\text { phosphate intravaginally }\end{array}$} & Males & $15.71 \pm 0.76$ & $8.000 \pm 1.155$ & $3.143 \pm 1.215$ & $0.714 \pm 0.756$ \\
\cline { 2 - 6 } & Females & $15.29 \pm 0.95$ & $8.143 \pm 1.069$ & $2.857 \pm 1.215$ & $1.143 \pm 0.690$ \\
\hline \multirow{2}{*}{$\begin{array}{l}\text { 4. Clindamycin phosphate } \\
\text { intravaginally + NaHS }\end{array}$} & Males & $16.29 \pm 0.76$ & $7.571 \pm 1.134$ & $2.571 \pm 0.787$ & $0.571 \pm 0.535$ \\
\hline \multirow{2}{*}{\begin{tabular}{l} 
5. Clindamycin phosphate orally \\
\cline { 2 - 6 }
\end{tabular}} & Females & $15.86 \pm 0.69$ & $8.714 \pm 0.951$ & $3.000 \pm 1.528$ & $1.143 \pm 0.690$ \\
\hline \multirow{2yyyyy}{*}{\begin{tabular}{l} 
6. Clindamycin phosphate orally + \\
\cline { 2 - 6 }
\end{tabular}} & Males & $16.14 \pm 0.90$ & $7.714 \pm 1.254$ & $3.143 \pm 0.690$ & $0.857 \pm 0.900$ \\
\cline { 2 - 6 } & Females & $16.29 \pm 0.95$ & $8.571 \pm 1.134$ & $3.286 \pm 1.254$ & $0.714 \pm 0.756$ \\
\cline { 2 - 6 }
\end{tabular}

An "open field" test was used to assess the behavioral responses of the offspring. The test results are shown in Table 4.

Thus, when evaluating the effect of the studied compounds on the offspring of rats, according to the "open field" test, we did not register any negative changes. All rats showed a sufficient level of resistance to stress, and indicators of interest (ambulation, ringing) and anxiety (grooming) did not go beyond the range of normal values.

\section{Discussion}

In the body, Hydrogen sulfide acts as a signaling molecule, a gas transmitter for which no specific receptors have been found. H2S molecular targets are various ion channels, receptors, enzymes and proteins that regulate a wide range of biochemical and physiological processes [13].

The content of Hydrogen sulfide in the body often changes as a result of pathological conditions and the use of pharmacological drugs. Thus, Hydrogen sulfide deficiency is associated with ischemic heart and brain disorders, mental retardation, atherosclerosis, hyperhomocysteinemia, etc. [6, 30, 31]. On the other hand, excessive production of Hydrogen sulfide is involved in the pathogenesis of inflammatory diseases, septic shock, stroke, etc. [5, 31].

This involvement of Hydrogen sulfide in the pathogenesis of various pathological conditions is due to the fact that it is involved in the regulation of a wide range of physiological and pathophysiological processes, such as vascular tone, neuromodulation, cytoprotection, inflammation, apoptosis and others [9, 12, 13, 29, 31].

No less interesting is the ability of Hydrogen sulfide to stimulate angiogenesis by stimulating the proliferation of endothelial cells [19, 32].

In this study, by serial administration of sodium hydrosulfide, we were able to achieve an increase in the background level of Hydrogen sulfide in all experimental animals, as in our previous studies [27].

Clindamycin phosphate when administered intravaginally did not create toxic effects on the mother and the embryo. The absence of toxic effects was confirmed by similar to the control group indicators of weight gain of pregnant rats, as well as indicators of weight and size of embryos on the 20th day of the study. In addition, the number of live and resorbed fetuses, as well as pre-implantation and post-implantation mortality did not differ statistically from the control group. There were also no changes in body weight gain and mental development of rats born to females who received Clindamycin phosphate in the form of suppositories during pregnancy.

Administration of Clindamycin phosphate to pregnant female rats during pregnancy had a negligible adverse effect on females and embryos. However, it was not possible to prove the statistical significance of differences with the control group.

The creation of excess Hydrogen sulfide significantly improved the studied parameters in both rats with intravaginal administration of Clindamycin phosphate and in rats that were not administered the drug. This was manifested by a significant increase in body weight gain of pregnant rats and rats born from them, an increase in anthropometric indicators of embryos, as well as a decrease in the number of resorbed fetuses and postimplantation mortality. Mental development of rats was also characterized by better performance.

Additional administration of sodium hydrosulfide to rats treated with Clindamycin phosphate orally counteracted the slight adverse effects of the drug and significantly improved the studied parameters.

Such results of our researches can be explained by increase in a placental blood-groove and increase in trophism of embryos. On the one hand, the reason for this effect is the vasodilating effect of Hydrogen sulfide on the vessels of the placental circulation, which was previously described in the scientific literature $[4,11,20]$. On the other 
hand, previous studies demonstrate the presence of Hydrogen sulfide in the ability to stimulate angiogenesis by stimulating the proliferation of endothelial cells $[7,18$, 29, 32].

Further experimental studies will expand our understanding of the effects of Hydrogen sulfide on the morphological structure and development of the placenta, as well as a clearer understanding of its involvement in the pathogenesis of pathological conditions associated with placental blood flow.

Regarding the genotoxicity of Clindamycin phosphate against the background of excess Hydrogen sulfide, we did not conduct such studies for technical reasons. Literature data indicate the absence of genotoxicity in both oral and intravaginal forms of Clindamycin phosphate, which was confirmed by the results of the Ames mutation test for Salmonella typhimurium, as well as the

\section{References}

[1] AHFS Drug Information 2018. McEvoy, G.K. (Ed.). (2018). Clindamycin Hydrochloride, Clindamycin Palmitate Hydrochloride, Clindamycin Phosphate. American Society of Health-System Pharmacists.

[2] Attene-Ramos, M.S., Nava, G.M., Muellner, M.G., Wagner, E.D., Plewa, M.J., \& Gaskins, H.R. (2010). DNA damage and toxicogenomic analyses of hydrogen sulfide in human intestinal epithelial FHs 74 Int cells. Environmental and Molecular Mutagenesis, 51(4), 304-314. https://doi.org/10.1002/ em.20546

[3] Attene-Ramos, M.S., Wagner, E.D., Plewa, M.J., \& Gaskins, H.R. (2006). Evidence that hydrogen sulfide is a genotoxic agent. Molecular Cancer Research: MCR, 4(1), 9-14. https://doi.org/ 10.1158/1541-7786.MCR-05-0126

[4] Bhatia, M. (2005). Hydrogen sulfide as a vasodilator. IUBMB Life, 57(9), 603-606. https://doi.org/10.1080/ 15216540500217875

[5] Bhatia, M. (2019). Understanding Hydrogen Sulfide in Inflammation: Opportunities and Challenges. Molecular and Cellular Therapies, 7, 9-14. https://doi.org/10.13052/mct20528426.712

[6] Cai, H., \& Wang, X. (2020). Effect of sulfur dioxide on vascular biology. Histology and Histopathology, 18290. Advance online publication. https://doi.org/10.14670/HH-18-290

[7] Chen, D.B., Feng, L., Hodges, J.K., Lechuga, T.J., \& Zhang, H. (2017). Human trophoblast-derived hydrogen sulfide stimulates placental artery endothelial cell angiogenesis. Biology of Reproduction, 97(3), 478-489. https://doi.org/10.1093/biolre/ iox105

[8] de With, K., Allerberger, F., Amann, S., Apfalter, P., Brodt, H.R., Eckmanns, T. ... Kern, W.V. (2016). Strategies to enhance rational use of antibiotics in hospital: a guideline by the German Society for Infectious Diseases. Infection, 44(3), 395-439. https://doi.org/10.1007/s15010-016-0885-z

[9] Gadalla, M.M., \& Snyder, S.H. (2010). Hydrogen sulfide as a gasotransmitter. Journal of Neurochemistry, 113 (1), 14-26. https://doi.org/10.1111/j.1471-4159.2010.06580.x

[10] Graham, K., Sinyangwe, C., Nicholas, S., King, R., Mukupa, S. Källander, K. ... Hamade, P. (2016). Rational use of antibiotics by community health workers and caregivers for children with suspected pneumonia in Zambia: a cross-sectional mixed methods study. BMC Public Health, 16(1), 897. https://doi.org/ micronucleus test in rats [1]. As for Hydrogen sulfide, as an exogenous agent, it has a genotoxic effect [2,3]. At the same time, as an endogenous gas transmitter, Hydrogen sulfide has a protective and reparative effect on DNA [16, $24,24,26]$.

\section{Conclusions}

1. Artificial increase in the background level of Hydrogen sulfide in pregnant rats leads to an increase in maternal weight gain, increased anthropometric indicators of embryos, as well as a decrease in the number of resorbed fetuses and postimplantation mortality and eliminates the small negative impact of high doses of Clindamycin phosphate administered orally.

2. Rats born from females with elevated levels of Hydrogen sulfide in the body show faster rates of weight gain and better mental development.

\subsection{6/s12889-016-3541-8}

[11] Greaney, J.L., Kutz, J.L., Shank, S.W., Jandu, S., Santhanam, L., \& Alexander, L.M. (2017). Impaired Hydrogen SulfideMediated Vasodilation Contributes to Microvascular Endothelial Dysfunction in Hypertensive Adults. Hypertension (Dallas, Tex.: 1979), 69(5), 902-909. https://doi.org/10.1161/ HYPERTENSIONAHA. 116.08964

[12] Kimura, H. (2011). Hydrogen sulfide: its production, release and functions. Amino acids, 41(1), 113-121. https://doi.org/ 10.1007/s00726-010-0510-x

[13] Kimura, H. (2014). Production and physiological effects of hydrogen sulfide. Antioxidants \& Redox Signaling, 20(5), 783793. https://doi.org/10.1089/ars.2013.5309

[14] Lamont, R.F., Keelan, J.A., Larsson, P.G., \& Jørgensen, J.S. (2017). The treatment of bacterial vaginosis in pregnancy with clindamycin to reduce the risk of infection-related preterm birth: a response to the Danish Society of Obstetrics and Gynecology guideline group's clinical recommendations. Acta Obstetricia et Gynecologica Scandinavica, 96(2), 139-143. https://doi.org/10.1111/aogs.13065

[15] Larsson, P.-G., Poutakidis, G., Adolfsson, A., Charonis, G., Bauer, P., \& Ekstrom, L. (2016). Treatment of Bacterial Vaginosis in Early Pregnancy and its Effect on Spontaneous Preterm Delivery and Preterm Premature Rupture of Membranes. Clin. Microbiol., 5(5), 1-8. http://dx.doi.org/10.4172/23275073.1000259

[16] Li, S., \& Yang, G. (2015). Hydrogen Sulfide Maintains Mitochondrial DNA Replication via Demethylation of TFAM. Antioxidants \& Redox Signaling, 23(7), 630-642. https:// doi.org/10.1089/ars.2014.6186

[17] Li, T., Wang, F., Zhang, Z., Zong, X., Bai, H., \& Liu, Z. (2021). Treatment of Bacterial Vaginosis: A Comparison of Metronidazole and Clindamycin on Human Anaerobic Bacteria and Lactobacilli. Retrieved from: https://doi.org/10.21203/ rs.3.rs-107727/v1

[18] Liao, W.X., Feng, L., Zhang, H., Zheng, J., Moore, T.R., \& Chen, D.B. (2009). Compartmentalizing VEGF-induced ERK2/1 signaling in placental artery endothelial cell caveolae: a paradoxical role of caveolin-1 in placental angiogenesis in vitro. Molecular Endocrinology (Baltimore, Md.), 23(9), 14281444. https://doi.org/10.1210/me.2008-0475

[19] Mahmood, A., Elnour, A.A., Ali, A.A., Hassan, N.A., Shehab, A., 
\& Bhagavathula, A.S. (2016). Evaluation of rational use of medicines (RUM) in four government hospitals in UAE. Saudi Pharmaceutical Journal: SPJ: the official publication of the Saudi Pharmaceutical Society, 24(2), 189-196. https://doi.org/ 10.1016/j.jsps.2015.03.003

[20] Materazzi, S., Zagli, G., Nassini, R., Bartolini, I., Romagnoli, S., Chelazzi, C. ... Patacchini, R. (2017). Vasodilator activity of hydrogen sulfide (H2S) in human mesenteric arteries. Microvascular Research, 109, 38-44. https://doi.org/10.1016/ j.mvr.2016.11.001

[21] Murphy, P.B., Bistas, K.G., \& Le, J.K. (2020). Clindamycin. In StatPearls. StatPearls Publishing.

[22] Nair, A.B., \& Jacob, S. (2016). A simple practice guide for dose conversion between animals and human. Journal of Basic and Clinical Pharmacy, 7(2), 27-31. https://doi.org/10.4103/ 0976-0105.177703

[23] Sexually Transmitted Diseases: Summary of 2015 CDC Treatment Guidelines. (2015). Journal of the Mississippi State Medical Association, 56(12), 372-375.

[24] Shackelford, R., Ozluk, E., Islam, M.Z., Hopper, B., Meram, A., Ghali, G., \& Kevil, C.G. (2021). Hydrogen sulfide and DNA repair. Redox Biology, 38, 101675. https://doi.org/10.1016/ j.redox.2020.101675

[25] Subtil, D., Brabant, G., Tilloy, E., Devos, P., Canis, F., Fruchart, A. ... Dessein, R. (2018). Early clindamycin for bacterial vaginosis in pregnancy (PREMEVA): a multicentre, doubleblind, randomised controlled trial. Lancet (London, England), 392(10160), 2171-2179. https://doi.org/10.1016/S01406736(18)31617-9

[26] Szczesny, B., Marcatti, M., Zatarain, J.R., Druzhyna, N., Wiktorowicz, J.E., Nagy, P. ... Szabo, C. (2016). Inhibition of hydrogen sulfide biosynthesis sensitizes lung adenocarcinoma to chemotherapeutic drugs by inhibiting mitochondrial DNA repair and suppressing cellular bioenergetics. Scientific Reports, 6, 36125. https://doi.org/ $10.1038 /$ srep36125

[27] Voloshchuk, N.I., Taran, I.V., \& Melnik, A.V. (2015). Vascular mechanism in the formation of diclophenac induced gastrotoxicity: the association with the level of hydrogen sulfide. Curierul Medical, 58(1), 7-11.

[28] Walger, P. (2016). Rationaler Einsatz von Antibiotika [Rational use of antibiotics]. Internist (Berl)., 57(6), 551-568. doi: 10.1007/s00108-016-0071-5

[29] Wang, R. (2002). Two's company, three's a crowd: can H2S be the third endogenous gaseous transmitter? FASEB Journal: Official Publication of the Federation of American Societies for Experimental Biology, 16(13), 1792-1798. https://doi.org/ 10.1096/fj.02-0211 hyp

[30] Whiteman, M., Le Trionnaire, S., Chopra, M., Fox, B., \& Whatmore, J. (2011). Emerging role of hydrogen sulfide in health and disease: critical appraisal of biomarkers and pharmacological tools. Clinical Science (London, England: 1979), 121(11), 459-488. https://doi.org/10.1042/CS20110267

[31] Xiao, Q., Ying, J., Xiang, L., \& Zhang, C. (2018). The biologic effect of hydrogen sulfide and its function in various diseases. Medicine, 97 (44), e13065. https://doi.org/10.1097/ MD.0000000000013065

[32] Zhou, Y., Li, X.H., Zhang, C.C., Wang, M.J., Xue, W.L., Wu, D.D., ... Zhu, Y.C. (2016). Hydrogen sulfide promotes angiogenesis by downregulating miR-640 via the VEGFR2/ mTOR pathway. American Journal of Physiology. Cell Physiology, 310(4), C305-C317. https://doi.org/10.1152/ ajpcell.00230.2015

\section{ОЦІНКА ЕМБРІОТОКСИЧНОСТІ ТА ФЕТОТОКСИЧНОСТІ КЛІНДАМІЦИНУ ФОСФАТУ ЗА УМОВИ НОРМАЛЬНОГО ТА ПІДВИЩЕНОГО РІВНЯ СИРОВАТКОВОГО ГІДРОГЕН СУЛЬФІДУ У ЩУРІВ \\ Таран І.В., Гребенюк Д.І., Волощук Н.І., Лозинська М.С., Назарчук О.А., Боднарчук О.В.}

Широке використання антибіотиків в клінічній практиці веде до розвитку антибіотикорезистентності та спонукає до пошуку нових шляхів модуляції ї терапевтичного впливу. Одним із потенційно успішних модуляторів може бути гідроген сульфід, проте механізми його дії потребують ретельного дослідження в тому числі й токсикологічного. Мета дослідження - вивчити вплив рівнів гідроген сульфіду на показники ембріотоксичності та фетотоксичності кліндаміцину фросфрату за умов перорального та інтравагінального введення. Експериментальне дослідження проводили на 60 вагітних самках щурів, які були розподілені на 6 дослідних груп: 1 група - група контролю; 2 група - надлишок сироваткового гідроген сульфріду; 3 група - кліндаміцину фоссрат інтравагінально; 4 група - кліндаміцину фоосфат інтравагінально на фоні надлишку сироваткового гідроген сульфіду; 5 група - кліндаміцину фосфрат перорально; 6 група - кліндаміцину фоссрат перорально на фоні надлишку сироваткового гідроген сульфіду. Вивчали динаміку набору маси вагітними самками, кількість жовтих тіл в яєчниках, кількість імплантаційних місць у матці, кількість живих та мертвих плодів, показники передімплантаційної та постімплантаційної летальності, а також динаміку набору маси тіла та психічний розвиток потомства за даними тесту "відкритого поля". Штучне підвищення фоонового рівня гідроген сульфіду в організмі вагітних щурів призводило до збільшення приросту маси материнського організму, збільшення маси та краніо-каудальних розмірів ембріонів, а також знижувало кількість резорбованих плодів та показників постімплантаційної летальності. Незначний токсичний вплив високих доз кліндаміцину фосфрату при його пероральному введенні нівелювався в групі з підвищеним рівнем фонового гідроген сульфріду. За даними тесту "відкритого поля" щурята, народжені від самок із підвищеним рівнем гідроген сульфіду в організмі, демонстрували більш швидкі темпи набору маси тіла та нормальні показники психічного розвитку.

Ключові слова: кліндаміцину фосфрат, гідроген сульфрід, ембріотоксичність, фетотоксичність. 